\title{
Some arachnidan peptides with potential medical application
}

\section{De Lima ME (1), Borges MH (2), Verano-Braga T (1), Torres FS (1), Montandon GG (1), Cardoso FL (1), Peixoto KDBA (1), Cardoso-Jr HC (1), Benelli MT (1)}

(1) Laboratory of Venoms and Animal Toxins, Department of Biochemistry and Immunology, Institute of Biological Sciences, Federal University of Minas Gerais, Belo Horizonte, Minas Gerais State, Brazil; (2) Center for Research and Development, Ezequiel Dias Foundation, Belo Horizonte, Minas Gerais State, Brazil.

ABSTRACT: The search for new active drugs that can alleviate or cure different diseases is a constant challenge to researchers in the biological area and to the pharmaceutical industry. Historically, research has focused on the study of substances from plants. More recently, however, animal venoms have been attracting attention and studies have been successful in addressing treatment of accidents. Furthermore, venoms and their toxins have been considered good tools for prospecting for new active drugs or models for new therapeutic drugs. In this review, we discuss some possibilities of using different toxins, especially those from arachnid venoms, which have shown some potential application in diseases involving pain, hypertension, epilepsy and erectile dysfunction. A new generation of drugs is likely to emerge from peptides, including those found in animal venoms.

KEY WORDS: arachnidan toxins, pain, epilepsy, cardiovascular effect, priapism, erectile function, scorpion, spider.

CONFLICTS OF INTEREST: There is no conflict.

\section{CORRESPONDENCE TO:}

MARIA ELENA DE LIMA, Laboratório de Venenos e Toxinas Animais, Departamento de Bioquímica e Imunologia, Instituto de Ciências Biológicas, Universidade Federal de Minas Gerais, Av. Antonio Carlos, 6627, Belo Horizonte, MG, 31.270-901, Brasil. Phone: +55 313409 2659. Email: melenalima@icb.ufmg.br. 


\section{INTRODUCTION}

The search for new drugs presents such great importance in medicine that pharmaceutical industries have invested significant resources in this field. Natural extracts, including those from some plants and animal products, have represented a source for medicines since ancient times. Such extracts usually include a mixture of compounds that can act by affecting different physiological functions, sometimes causing undesirable effects. Besides, some components can constitute potential pharmaceutical models. Nowadays, the focus is on the search for active substances present in natural products, to the detriment of extracts, with to the objective of separating undesirable from desirable components. Obtaining active compounds is now considered far better than developing new extraction methodologies in order to purify and test their activities, most notable among these technologies are mass spectrometry (MS), high performance liquid chromatography (HPLC) and twodimensional electrophoresis. Similarly, a range of diverse biological assays are available.

Morphine (after Morpheus, the Greek God of dreams) is a classic example of natural compounds useful in medicine. Opium, obtained from poppy juice (Papaver somniferum), contains more than twenty distinct alkaloids, including morphine. A reference of its use can be found in the writings of Theophrastus (371-287 B.C.). Opium was introduced into Asia by Arabian traders, mainly to control dysentery. Paracelsus (1493-1541) seems to have popularized the use of opium in Europe. Then, by the middle of the sixteenth century, several uses of opium were appreciated. In 1806, Friedrich Sertürner isolated morphine, a pure substance, which was followed by the isolation of other active alkaloids. These purified substances are nowadays widely used in medicine - for a review, see Reisine and Pasternak (1).

In this context, traditional beliefs should also be considered: for example, alcoholic infusions containing venomous animal parts used to be employed to "treat" human victims of accidents. Additionally, some people believed that eating the head of the venomous animal is an effective treatment against scorpion stings (2)

More recently, some peptides derived from venoms of animals - including scorpions, spiders, amphibians, snakes and marine organisms - have proven to induce analgesia. Many of these peptides selectively inhibit voltage-activated $\mathrm{Ca}^{2+}$ and $\mathrm{Na}^{+}$ channels, acid-sensitive ion channels (ASIC) or glutamate ionotropic receptors. 
The first peptide approved for analgesic therapy (Prialt $\circledast$, Elan Pharmaceuticals Inc., USA) is a synthetic version of $\omega$-conotoxin MVIIA, a peptide purified from the venom of the fish-eating marine snail Conus magnus, which can selectively block $\mathrm{N}$-type calcium channels in pain pathways $(3,4)$.

Some studies on peptides had also prefigured the design of novel drugs for treating neurological disorders. In this context, epilepsy has been considered a potential focus of attention because it involves neuronal substrates many of which are neurotoxin action sites. Thus, venoms may be particularly useful for neuroprotection and antiepileptic drug research.

A classic example of a successful association between medicine and toxinology is the development of captopril - an antihypertensive drug globally used nowadays that was developed from a toxin model of Bothrops jararaca venom $(5,6)$. Other peptides from different species, such as scorpions, have been studied as possible alternatives models to new antihypertensives.

This review focuses on arachnidan peptides that show a possible application as pharmaceuticals. This paper is solely concerned with describing peptides that present cardiovascular, antiepileptic and antinociceptive effects and also potentiate erectile response.

\section{PEPTIDES WITH ANALGESIC PROPERTIES}

Among natural molecules, several peptides from different animals, including arthropods, have recently been studied as antinociceptive agents.

Pain is a complex and multidimensional phenomenon that is subjective and unique to each individual. It is recognized as a multifactorial sensory experience in which several mechanisms are involved. Moreover, its intensity and duration may differ. Unrelieved pain can deeply affect patients' lives and its subjective nature makes it difficult to assess (7).

Nowadays, some neurochemical mechanisms at the spinal cord level are understood, as are the intricate interaction between inhibitory and excitatory neural pathways. There are several potential targets for analgesics including receptors, enzymes, ion channels and signaling molecules. The discovery of subtype-specific toxins that affect different ion/receptor channels has provided targets for pharmacological intervention. A number of novel approaches using animal toxins to relieve pain are currently under investigation. Huwentoxin-I, a N-type calcium 
channel blocker isolated from the venom of the Chinese tarantula Ornithoctonus huwena, has reduced nociceptive response in a dose-dependent manner when administrated intrathecally at lower doses and its antinociceptive effect was identical to that of $\omega$-conotoxin MVIIA, in the rat model of the formalin test (8).

Another calcium toxin, w-agatoxin IVA, from the venom of the funnel web spider Agelenopsis aperta, has shown selectivity toward P-type calcium channel and enhanced the agonist-induced tail flick antinociception when co-administered spinally with morphine and clonidine (9-11). Pha1 $\beta$, from the Brazilian armed spider Phoneutria nigriventer, has blocked calcium channels when administered spinally in rodent models with acute and persistent pain. Native and recombinant Pha1 $\beta$ has demonstrated an efficient antinociception effect in a thermal model of pain and was more effective than $\omega$-conotoxin MVIIA in preventing and reversing persistent chemical and neuropathic pain (12).

The function of AMPA/kainate receptors (calcium-permeable) on central the nociceptive process has been studied using Joro spider toxin (JSTX) and philanthotoxin, which can reduce allodynia and hyperalgesia when administered intrathecally, indicating a possible involvement of these channels in spinal pain pathways (13-15).

Many other ion channels and receptors are known to mediate some types of pain. For example, voltage-gated sodium channels (VGSCs) play a critical role in modulating the excitability of most neurons, including nociceptive sensory neurons. VGSCs are the target of numerous common analgesics. Recently, new data have proven that loss-of-function mutations in the sodium channel subtype Nav1.7 are the cause of channelopathy-associated insensitivity to pain while gain-of-function mutations are the origin of inherited erythromelalgia and paroxysmal extreme pain disorder (16-22).

Some spider toxins present high selectivity to VGSC subtypes, including ProTx-II, a toxin isolated from the tarantula Thrixopelma prurient, which is 100 -fold more selective for NaV1.7 than other sodium channel subtypes (23-25). Similar to ProTx-II, some $\beta$-scorpion toxins act by reducing channel conductance and interacting with the voltage sensor, though these scorpion toxins may have low affinity for NaV1.7 channels (26). Given the crucial role of this VGSC subtype in human pain perception, ProTx-II may be an attractive tool in the search for novel analgesics. 
Several Asian scorpions are commonly employed in Chinese medicine to treat chronic pain, including Buthus martens Karsch (BmK). Two venom toxins of this species - namely BmK IT-AP and BmK dIT-AP3 - exhibited analgesic effects on mice. Moreover, BmK dIT-AP3 showed peripheral antihyperalgesia and antinociception in carrageenan induced inflammation in rats (27-29). BmK AS, another toxin from the same venom, also induces peripheral antihyperalgesia and antinociception in carrageenan-induced inflamed rats, possibly by modulating the sodium channel in nociceptors (30). When intrathecally injected, BmK AS markedly reduced formalin-evoked biphasic nociceptive responses in a dose-dependent manner (31). BmK AS1, another similar toxin, produced an antinociceptive effect on the rat peripheral nervous system and spinal cord, this effect was attributed to the modulation of tetrodotoxin-resistant and tetrodotoxin-sensitive sodium channels in peripheral and central neurons $(32,33)$.

A new class of analgesics found in the venom of the tarantula Psalmopoeus cambridgei, psalmotoxin 1, specifically blocks the acid-sensitive ion channel, a proton-gated sodium channel that plays a central role in pathological conditions (34). This toxin presented analgesic properties against thermal, mechanical, chemical, inflammatory and neuropathic pain in rodents. Its action is exerted by blocking ASIC1a and activating the endogenous enkephalin pathway (35).

Channels involved in mechanical hyperalgesia are not fully understood. It was hypothesized that molecules that could block mechanosensitive and stretch-activated channels may reduce mechanical hyperalgesia. Park et al. (36) found that GsMTX4, a tarantula toxin from the Grammostola spatulata venom, attenuated pain-related response using the Randal Sellito model, but failed to relieve mechanical allodynia evoked by Von Frey hairs. Since mechanical pain is an important clinical problem, GsMTx4 might be useful for treating it. The mechanism underlying the analgesic action of GsMTx4 remains unknown.

Other channels are also involved in different types of pain, such as those from the transient receptor potential (TRP) channels group, e.g. TRPV1, thought to mediate inflammatory thermal hyperalgesia (37), TRPM8 and TRPA1, both described to mediate pain associated with cold (38-40). Thus, molecules that can modulate these targets are of interest - for a review, see Cortright and Szallasi (41).

Diverse pain models and unique times of activation/inactivation of subtype ionchannels may be measured to evaluate the use of these toxins in treating pain. The 
development of tolerance to some traditional drugs, such as opioids, can require the use of a combined therapy. Using subtype-specific toxins and other channel modulators that participate in pain might produce an effective analgesia.

\section{PEPTIDES WITH ANTIEPILEPTIC EFFECTS}

Epilepsy is one of the most common neurological disorders, and affects 40 to 50 million people throughout the globe (42). It is characterized by the occurrence, over a period of 24 hours, of at least two episodes of excessive and uncontrolled activity of the central nervous system caused by an imbalance between excitatory and inhibitory neurotransmitters (43).

The affected person is predisposed to suffer a convulsion when the basal excitability level of the nervous system increases above a critical threshold (43). Convulsive episodes occur as a consequence of excessive hypersynchronous discharges from neuronal aggregates in the brain (44). A focal seizure is triggered by an abnormal electrical discharge in the cerebral cortex, restricted to a particular area. The clinical expression of this abnormal electrical firing is specific to the stimulated cortical area. The term "seizure" refers to a crisis with predominant motor manifestations (45). Frequently, seizures cause injuries that induce neuronal cell death. There are numerous factors that contribute to this process, such as genetic components and neuronal excitotoxicity, due to excessive release of glutamate, an excitatory neurotransmitter of the nervous system. During a crisis, there is a reduction of the inhibitory neurotransmitter GABA and an increased release of glutamate from presynaptic terminals. Glutamate crosses the synaptic cleft to bind to the N-methylD-aspartate (NMDA) glutamate receptors, causing prolonged depolarization and excessive accumulation of intracellular calcium, triggering signaling cascades, including generation of reactive oxygen species (ROS), mitochondrial damage and acute neuronal cell death (46-49).

Nowadays, new anticonvulsant drugs available on the market, act on several molecular targets, including AMPA and NMDA glutamate receptors. Nevertheless, drugs employed for early treatment do not appear to affect the long-term prognosis, especially in relation to epilepsy severity or prolonged remission (50). Moreover, antiepileptic drugs may cause side effects, e.g. chronic toxicity, cognitive impairment, sedation and teratogenesis in chronic patients (51). 
Thus, neuroprotective drug leads are extensively researched by the pharmaceutical industry, by seeking new molecules in animal venoms, e.g. cone snails, spiders and scorpions. Many molecules have been isolated from these venoms and studies have shown that they have specific targets in the peripheral or central nervous system, by acting on $\mathrm{Ca}^{+2}$ and $\mathrm{Na}^{+}$channels and in the glutamatergic system. The observation that these compounds bound to specific targets on neurons constituted evidence that they could possibly lead to antiepileptic drugs (52).

Several toxins isolated from Phoneutria nigriventer spider venom bind to ion channels - including PnTx3-3 and PnTx3-4 - and inhibit calcium influx and glutamate exocytosis in isolated nerve endings, thus showing a neuroprotective effect that prevents both neuronal death and loss of neurotransmission in hippocampus CA1 after ischemia induced in vitro (53-60). There is evidence that PnTx3-3 and PnTx3-4 also offer neuroprotection in vivo, which suggests that these molecules may be used for studies on neurodegenerative diseases, such as epilepsy (61). The $\mathrm{Na}^{+}$channel is involved in membrane excitability and is related to several pathologies including epilepsy. Therefore, toxins that bind to this channel may be of interest. There are $P$. nigriventer toxins that act on neuronal $\mathrm{Na}^{+}$channel, e.g. PnTx1 and toxins from the PnTx2 group (PnTx2-1, PnTx2-5 and PnTx2-6) (62, 63).

On the other hand, homologous toxins from the PnTx4 group [PnTx4-3, PnTx4(6-1) and PnTx4(5-5)] from $P$. nigriventer are known to interact with the glutamatergic system (64-67). PnTx4(5-5) reversibly inhibits ionic currents mediated through NMDA receptors in rat hippocampal neurons and combined with toxins from the PnTx4 group inhibits glutamate uptake in the micromolar concentration range (66, 67). These toxins appear to be toxic only for insects. Intracerebroventricular injections of high doses $(\sim 30 \mu \mathrm{g})$ of these toxins in mice did not show any visible effect $(64,67)$. However, pharmacological studies on PnTx4 toxins in mammals are incipient for proposing their possible use as drug models.

Scorpion toxins that act on $\mathrm{Na}^{+}$channels can be divided into $\alpha$-toxins that bind to site-3 and slow or block sodium channel inactivation, and $\beta$-toxins that specifically bind to site-4 thus altering the activation of these channels $(68,69)$. Buthus martensi Karsch $(B m K)$ is an Asian scorpion of the Buthidae family, whose venom has been used for treatment of neurological diseases such as epilepsy. Several toxins have been isolated and characterized from this venom, including $\alpha$ and $\beta$-neurotoxins, that 
present an antiepileptic effect in rats (70). BmK IT2 modulates $\mathrm{Na}^{+}$channels in the hippocampus and constitutes an attractive tool for studies on this pathology (71).

The diversity of toxins from scorpions and spiders that act on ion channels, a result of their evolutionary process, represents an arsenal of possible medical drug leads. However, much remains to be done before these molecules can be used in the treatment of neuronal pathologies.

\section{PEPTIDES WITH CARDIOVASCULAR EFFECTS}

Cardiovascular diseases are the main cause of death in modern life. Elevated blood pressure reveals an independent, linear and continuous risk of developing cardiovascular diseases (72). Deaths related to coronary heart disease and strokes are mostly caused by hypertension (73).

Several toxins, isolated from different venom sources, act on all cardiovascular system levels, e.g. integrins and desintegrins that disrupt blood coagulation cascade; a toxin from Androctonus australis garzonii venom that is able to induce atrial natriuretic peptide secretion; and BmK I toxin, from Buthus martensi scorpion venom, that is able to modulate cardiac contraction (74-80). Nevertheless, we will focus on bradykinin-potentiating peptides (BPPs) in this section.

By the end of the 1940s, venom research led to the discovery of bradykinin (BK) by Rocha e Silva et al. (81). The authors were studying Bothrops jararaca venom and reported that extracts of this snake venom or trypsin, when incubated with the globulin fraction of dog plasma, released a substance that induced contraction of isolated guinea pig ileum. They called this substance bradykinin (from Greek brady, slow and kinesia, movement) - for a review, see Bhoola et al. (82).

The kallikrein-kinin system is involved in the regulation of smooth-muscle contraction, endothelium-dependent vasodilatation, nociception and inflammation. Kinins are produced and accumulated in inflamed tissues, thus triggering the inflammatory process through pain, redness, heat and swelling. These active peptides are formed from their precursors, the kininogens, through the action of kallikreins, a specific serine protease (82).

The broad spectrum of kinin action is mediated by $G$ protein-coupled receptors, pharmacologically classified as $B_{1}$ and $B_{2}$ subtypes, which present seven transmembrane domains. BK is able to induce vasodilatation, thus decreasing blood 
pressure mainly by activating $B_{2}$ receptors and triggering the production of nitric oxide (NO), a potent vasodilator (83-87).

Bradykinin-potentiating peptides (BPPs), first described by Ferreira et al. (5), present low molecular weight with no disulfide bridges that are able to potentiate the pharmacological effects of BK, since they can induce hypotension and contraction of smooth muscle. Several BPPs are able to inhibit angiotensin-converting enzyme (ACE), a key enzyme in blood pressure control. Therefore, BPPs present great biotechnological interest as potential drugs to treat several cardiovascular diseases. As a matter of fact, the molecular features of BPPs led to the development of Captopril囚, the first commercial ACE inhibitor, currently used for cardiovascular diseases treatment including hypertension $(6,87,88)$.

After Ferreira's discovery, several BPPs have been isolated from snake venoms. These peptides have a conserved consensus at both extremities, e.g. a pyroglutamic acid residue at the $\mathrm{N}$-terminal and two prolines at the C-terminal $(5,89,90)$.

So far, only seven BPPs have been identified in the arthropod venoms (Table 1). In 1993, Ferreira et al. (91) isolated and characterized a peptide $T$ from the venom of Tityus serrulatus, a South American scorpion. That was the first report of a BPP obtained from arthropod venom. The primary structure of peptide $T$ is quite different from those of other BPPs (Table 1).

Recently, our group has identified a new BPP family, called hypotensins (Table 1). Like all known BPPs, these peptides present no cysteine residues, so that they lack disulfide bridges and comprise unstructured random-coiled peptides, as observed from circular dichroism and 2D-RMN data. The presence of two proline residues at the C-terminal portion was noteworthy, as shown in classic BPPs (92). Besides potentiating BK, TsHpt-I - a member of this family - can induce a transient hypotensive effect, independently of BK administration, and an NO-dependent vasodilatation in aortic ring preparations (92). Diverging from all known BPPs, TsHptI acts as an agonist in relation to kinin receptors and does not inhibit ACE. A structural-functional study was performed and demonstrated that the C-terminal doublet, Pro-Pro, of these molecules was important to potentiate BK as well as the positively charged lysine residue, just before Pro-Pro residues, was crucial for activation of kinin receptors by these peptides. 
Table 1 - BPPs isolated from arthropod venoms

\begin{tabular}{c|c|c|c}
\hline Names & Species & Primary structures & References \\
\hline BPP-S & Scaptocosa raptoria & <EAPWPDTISPP_ & 93 \\
\hline $\mathrm{K}_{12}$ & Buthus occitanus & LRDYANRVINGGPVEAAGPPA & 94 \\
\hline Peptide T & Tityus serrulatus & KKDGYPVEYDRAY & 91 \\
\hline TsHpt-I & Tityus serrulatus & AEIDFSGIPEDIIKQIKETNAKPPA & 92 \\
\hline TsHpt-II & Tityus serrulatus & AEIDFSGIPEDIIKEIKETNAKPPA & 92 \\
\hline TsHpt-III & Tityus serrulatus & AEIDFSGIPEDIIKQIKETNAKPP_ & 92 \\
\hline TsHpt-IV & Tityus serrulatus & AEIDFSGIPEDIIKEIKETNAKPP_- & 92 \\
\hline
\end{tabular}

$<$ E: pyroglutamic acid; alignments were obtained from PP residues.

\section{PEPTIDES THAT POTENTIATE ERECTILE FUNCTION}

Erectile dysfunction (ED) is defined as the persistent inability to achieve or maintain an erection sufficient for a satisfactory sexual performance (95). Many factors can contribute to the development of ED including smoking and vascular diseases such as atherosclerosis, hypertension, diabetes mellitus, besides anxiety and depression (96-102). The use of specific pharmacological medications, including antihypertensive drugs, diuretics, cardiac medications, hormones and antidepressants can induce ED. Nowadays, a profound change has occurred in current strategies for the pharmacological treatment of ED, mainly with the advent of effective oral erectogenic drugs (103).

Penile erection is a neurovascular phenomenon that depends upon neural integrity, functional vascular system and healthy cavernosal tissue $(101,103,104)$. The penis is innervated by both autonomic and somatic nerve fibers. Sympathetic and parasympathetic nerves from the pelvis ramify to form the cavernous nerves (101, 104). Upon sexual stimulation, neurotransmitters are released from cavernous nerve terminals and smooth muscle endothelium. Similarly, vasoactive relaxing factors from the endothelial cells of the penis, which relax arteries and arterioles supplying the erectile tissue, increase the penile blood flow and ultimately produce a penile erection $(101,103,105)$.

Cholinergic nerves, noradrenergic nerves, noncholinergic and nonadrenergic nerves (NANC), nitric oxide (NO), and other factors such as vasoactive intestinal peptide (VIP) and calcitonin gene-related peptide (CGRP) mediate smooth muscle relaxation 
of the corpus cavernosum $(106,107)$. Moreover, sheer stress and muscarinic acetylcholine receptors on the trabecular endothelium stimulate the production of NO, an important factor for penile erection (98).

The nitric oxide pathway is of critical importance in physiological induction and maintenance of erection (107-109). NO is synthesized from L-arginine by the action of NO synthase (NOS) - three isoforms of this enzyme are known: neuronal NOS (nNOS), endothelial NOS (eNOS) and inducible NOS (iNOS) $(109,110)$. After being synthesized, NO is released and diffuses into smooth muscle cells, activating the soluble form of guanylate cyclase enzyme, thus increasing the concentration of cyclic guanosine monophosphate (cGMP). The latter activates cGMP-dependent ion channels, reducing cytosolic calcium via sequestration, extrusion and opening of potassium channels, which result in hyperpolarization of smooth muscle cells of the corpus cavernosum, in addition to activating myosin chain phosphatases. Finally, increased cGMP leads to smooth muscle relaxation, increased arterial flow, and corporal venous-occlusion with a subsequent penile erection. The hydrolysis of cGMP by phosphodiesterase type 5 (PDE 5) leads to a corpus cavernosum contraction $(103,108,111-116)$.

A corpus cavernosum contraction results in penile flaccidity and is maintained by increased intracellular calcium, which binds to calmodulin leading to change in its conformation, exposing sites of interaction with myosin-light-chain kinase (MLCK). Kinase catalyses phosphorylation of myosin light chains that activate myosin ATPase, hydrolyzing ATP in such a way as to provide energy for muscle contraction. In another pathway, after cytosolic calcium returns to basal levels, the activation of excitatory receptors coupled to $G$ protein (Rho A) can also cause contraction. Additionally, Rho A activates Rho-kinase, which phosphorylates and thereby inhibits the regulatory subunit of smooth muscle myosin phosphatase and prevents dephosphorylation of myofilaments, thus maintaining a contractile tone $(116,117)$. Nowadays, the main pharmacotherapy for treating ED uses PDE5 inhibitors, including sildenafil (Viagra $\AA$ ), taladafil (Cialis $\AA$ ) and vardenafil (Levitra $\left.{ }^{\circledR}\right)$ (99, 101, $113,116)$. The action mechanism of these inhibitors requires intact NO-relaxing nerve fibers and healthy corpus cavernosum endothelium. The drugs inhibit the phosphodiesterase type5, thus preventing hydrolysis of cGMP and consequently maintaining erection. Moreover, PDE5 inhibitors, mainly sildenafil, are not efficient in 
treating patients with radical prostatectomy or vascular diseases, such as diabetes, where NO production is impaired (113).

Interestingly, peptides present in animal venoms, as scorpions and spiders, among other symptoms, cause priapism - a painful penile erection that is persistent or unrelated to sexual stimulation (118). These venoms, as well as some peptides purified from them, have shown efficiency in promoting priapism and erection in different experimental models $(53,115,116,119-121)$.

Animal venoms or purified toxins evoke complex effects on ion channels, mainly sodium, potassium and calcium channels (56, 66, 122-127). Experimental approaches using bioassay cascade have demonstrated that crude venom from the scorpion Tityus serrulatus causes relaxation in rabbit and human cavernosal smooth muscle in vitro, by a mechanism dependent on NO release from nitrergic nerves, and this effect was decreased with non-selective NOS inhibitor, N(omega)-nitro-Larginine methyl ester (L-NAME) $(127,128)$. Additionally, Ts3, a toxin isolated from this venom, causes relaxation of NO-dependent corpus cavernosum in rabbits, a response blocked by L-NAME and tetrodotoxin (TTX) (129). Other scorpion venoms, as those from Androctonus australis and Buthotus judaicus, have also been reported to cause relaxation of rabbit corpus cavernosum. This effect was inhibited with LNAME, 7-nitroindazole, 1H-[1,2,4] oxadiazole [4,3-alquinoxalin-1-one] and TTX (119). Spider venoms are composed of distinct proteins, peptides and biologically active molecules, most of them neurotoxins (56). These venoms have been described as potentially useful for future discovery and development of new biologically active molecules with medical application $(66,115,116,122)$. The crude venom of Phoneutria nigriventer contains potent neurotoxins that cause excitatory symptoms $(53,56)$. Some of these toxins, namely PnTx2-5 and PnTx2-6, share $89 \%$ of similarity in their amino acid sequence and have been observed to stimulate relaxation of the corpus cavernosum smooth muscle in rabbits, rats and mice, inducing penile erection $(54,115,116,121,130,131)$. Both toxins were described as site-3 toxins, according to their effects on sodium channels $(125,132)$. As observed for scorpion toxins, priapism induced by these toxins has been directly associated with the nitric oxide pathway in rats and mice and this effect has been inhibited by LNAME $(115,116,131)$.

Nunes et al. (115) proposed that improved effect of PnTx2-6 on rat penile erection seems to be mediated by relaxation of vasculature and smooth muscle in the corpus 
cavernosum via NO release from NANC nerve terminals. Moreover, there is evidence that specific receptors for the toxin exist in the corpus cavernosum, following this tissue labeling after injection of PnTx2-6 labeled with technetium-99 (115).

Another study has demonstrated that some genes are under-expressed and others in the oxide nitric pathway are over-expressed, as ednrb that activates the Larginine/NO/cGMP pathway and is involved in the relaxation of the corpus cavernosum (133). This study strengthens the hypothesis by Nunes et al. (115) that the priapism induced by PnTx2-6 is a consequence of a highly specific interference of this neurotoxin with the NO pathway. The difficulty in obtaining these toxins is a limiting factor for their use. Constructing recombinant toxins, using protein engineering techniques, is an important alternative to obtain sufficient material and can overcome these problems.

The cDNA for PnTx2-6 toxin from Phoneutria nigriventer venom was cloned and expressed as a thioredoxin fusion protein in the cytoplasm of Escherichia coli and the erectile response, as with native PnTx2-6, was significantly potentiated after subcutaneous injection with the recombinant PnTx2-6. There is clear evidence of the pharmacological and therapeutic potential uses of these toxins from animal venoms for ED treatment. However, many studies are still necessary, due to the high toxicity of these molecules and the different collateral effects that they may provoke. In addition, we believe that these molecules might constitute adequate models for the design of other therapeutic drugs, targeting different sites not yet explored for potentiating erectile function or treating erectile dysfunction.

\section{FINAL REMARKS}

The aforementioned peptides that exhibit analgesic, antiepileptic and antihypertensive activities and potentiate erectile dysfunction represent only a small sample of a plethora of molecules from arthropods that have been explored due to their potential application in medicine and in biotechnology (116, 134-137). Furthermore, arthropods have presented molecules with potent antibiotic and insecticide effects, as well as properties for treating autoimmune diseases and some myotonic dystrophy $(123,135,138-141)$.

Venoms, including those from arthropods, showing biological activities with various potential uses in medicine and biothecnology have recently been reviewed (142). 
It is hoped that a new generation of drugs based on active peptides can be produced in the next future. Arachnidan and other animal venoms revealed a new source for the discovery and formulation of active drugs.

Finally, venoms, for a long time considered dangerous and exotic substances, now prove to be potentially new sources to cure different diseases.

\section{ACKNOWLEDGEMENTS}

Our research group has been supported by the National Council for Scientific and Technological Development (CNPq), the Coordination for the Improvement of Higher Education Personnel (CAPES), the Minas Gerais State Research Foundation (FAPEMIG) and National Institute of Science and Toxin Technology (INCTTOX Fapesp).

\section{REFERENCES}

1. Reisine T, Pasternak G. Opioid analgesics and antagonists. In: Hardman JG, Limbird LE, Molinoff PB, Ruddon RW, Gilman, AG, editors. Goodman and Gilman's the pharmacological basis of therapeutics. $9^{\text {th }}$ ed. New York: McGraw-Hill; 1996. p. 521-55.

2. Magalhães OC. Escorpionismo IV. Memória. In: Monografias do Instituto Oswaldo Cruz. Rio de Janeiro: Imprensa Nacional; 1946. 220 p.

3. Wallace MS. Ziconotide: a new nonopioid intrathecal analgesic for the treatment of chronic pain. Expert Rev Neurother. 2006;6(10):1423-8.

4. Cury Y, Picolo G. Animal toxins as analgesics: an overview. Drug News Perspect. 2006;19(7):381-92.

5. Ferreira SH, Bartelt DC, Greene LJ. Isolation of bradykinin-pontentiating peptides from Bothrops jararaca venom. Biochemistry. 1970;9(1):2583-93.

6. Ondetti MA, Rubin B, Cushman DW. Design of specific inhibitors of angiotensinconverting enzyme: new class of orally active antihypertensive agents. Science. 1977;196(4288):441-4.

7. Romero-Reyes M, Graff-Radford S. Is there hope for chronic pain and headache? Headache. 2007;47(8):1262-71.

8. Chen JQ, Zhang YQ, Dai J, Luo ZM, Liang SP. Antinociceptive effects of intrathecally administered huwentoxin-I, a selective $\mathrm{N}$-type calcium channel blocker, in the formalin test in conscious rats. Toxicon. 2005;45(1):15-20. 
9. Mintz IM, Adams ME, Bean BP. P-type calcium channels in rat central and peripheral neurons. Neuron. 1992;9(1):85-95.

10. Mintz IM, Venema VJ, Swiderek KM, Lee TD, Bean BP, Adams ME. P-type calcium channels blocked by the spider toxin $\omega$-aga-IVA. Nature. 1992;355(1):827-9.

11. Roerig SC, Howse KM. w-Agatoxin IVA blocks spinal morphine/clonidine antinociceptive synergism. Eur J Pharmacol. 1996;314(3):293-300.

12. Souza AH, Ferreira J, Cordeiro MN, Vieira LB, De Castro CJ, Trevisan G, et al. Analgesic effect in rodents of native and recombinant Pha1 $\beta$ toxin, a high-voltageactivated calcium channel blocker isolated from armed spider venom. Pain. 2008;140(1):115-26.

13. Kawai N, Miwa A, Shimazaki K, Sahara Y, Robinson HP, Nakajima T. Spider toxin and the glutamate receptors. Comp Biochem Physiol C. 1991;98(1):87-95.

14. Sorkin LS, Yaksh TL, Doom CM. Mechanical allodynia in rats is blocked by a Ca2+ permeable AMPA receptor antagonist. Neuroreport. 1999;10(17):3523-6.

15. Stanfa LC, Hampton DW, Dickenson AH. Role of Ca2+-permeable non-NMDA glutamate receptors in spinal nociceptive transmission. Neuroreport. 2000;11(14): 3199-202.

16. Cox JJ, Reimann F, Nicholas AK, Thornton G, Roberts E, Springell K, et al. An SCN9A channelopathy causes congenital inability to experience pain. Nature. 2006;444(7121):894-8.

17. Ahmad S, Dahllund L, Eriksson AB, Hellgren D, Karlsson U, Lund PE, et al. A stop codon mutation in SCN9A causes lack of pain sensation. Hum Mol Genet. 2007; 16(17):2114-21.

18. Goldberg YP, MacFarlane J, MacDonald ML, Thompson J, Dube MP, Mattice M, et al. Loss-of-function mutations in the Nav1.7 gene underlie congenital indifference to pain in multiple human populations. Clin Genet. 2007;71(4):311-9.

19. Yang Y, Wang Y, Li S, Xu Z, Li H, Ma L, et al. Mutations in SCN9A, encoding a sodium channel alpha subunit, in patients with primary erythermalgia. J Med Genet. 2004;41(3):171-4.

20. Han C, Rush AM, Dib-Hajj SD, Li S, Xu Z, Wang Y, et al. Sporadic onset of erythermalgia: a gain-of-function mutation in Nav1.7. Ann Neurol. 2006;59(3):553-8.

21. Dib-Hajj SD, Cummins TR, Black JA, Waxman SG. From genes to pain: Nav1.7 and human pain disorders. Trends Neurosci. 2007;30(1):555-63. 
22. Fertleman CR, Baker MD, Parker KA, Moffatt S, Elmslie FV, Abrahamsen B, et al. SCN9A mutations in paroxysmal extreme pain disorder: allelic variants underlie distinct channel defects and phenotypes. Neuron. 2006;52(5):767-74.

23. Middleton RE, Warren VA, Kraus RL, Hwang JC, Liu CJ, Dai G, et al. Two tarantula peptides inhibit activation of multiple sodium channels. Biochemistry. 2002;41(50):14734-47.

24. Smith JJ, Cummins TR, Alphy S, Blumenthal KM. Molecular interactions of the gating modifier toxin ProTx-II with NaV 1.5: implied existence of a novel toxin binding site coupled to activation. J Biol Chem. 2007;282(17):12687-97.

25. Schmalhofer WA, Calhoun J, Burrows R, Bailey T, Kohler MG, Weinglass AB, et al. ProTx-II, a selective inhibitor of NaV1.7 sodium channels, blocks action potential propagation in nociceptors. Mol Pharmacol. 2008;74(5):1476-84.

26. Cestele S, Qu Y, Rogers JC, Rochat H, Scheuer T, Catterall WA. Voltage sensortrapping: enhanced activation of sodium channels by beta-scorpion toxin bound to the S3-S4 loop in domain II. Neuron. 1998;21(4):919-31.

27. Xiong YM, Lan ZD, Wang M, Liu B, Liu XQ, Fei H, et al. Molecular characterization of a new excitatory insect neurotoxin with an analgesic effect on mice from the scorpion Buthus martensi Karsch. Toxicon. 1999;37(8):1165-80.

28. Guan R, Wang CG, Wang M, Wang DC. A depressant insect toxin with a novel analgesic effect from scorpion Buthus martensii Karsch. Biochim Biophys Acta. 2001;1549(1):9-18.

29. Goudet C, Chi CW, Tytgat J. An overview of toxins and genes from the venom of the Asian scorpion Buthus martesi Karsch. Toxicon. 2002;40(9):1239-58.

30. Chen B, Ji Y. Antihyperalgesia effect of BmK AS, a scorpion toxin, in rat by plantar injection. Brain Res. 2002;952(2):322-6.

31. Liu T, Pang XY, Jiang F, Bai ZT, Ji HY. Anti-nociceptive effects induced by intrathecal injection of BmK AS, a polypeptide from the venom of Chinese-scorpion Buthus martensi Karsch, in rat formalin test. J Ethnopharmacol. 2008;117(2):332-8.

32. Tan ZY, Mao X, Xiao H, Zhao ZQ, Ji YH. Buthus martensi Karsch agonist of skeletal-muscle RyR-1, a scorpion active polypeptide: antinociceptive effect on rat peripheral nervous system and spinal cord, and inhibition of voltage-gated $\mathrm{Na}(+)$ currents in dorsal root ganglion neurons. Neurosci Lett. 2001; 297(2):65-8. 
33. Tan ZY, Xiao H, Mao X, Wang CY, Zhao ZQ, Ji YH. The inhibitory effects of BmK IT2, a scorpion neurotoxin on rat nociceptive flexion reflex and a possible mechanism for modulating voltage-gated Na+ channels. Neuropharmacology. 2001;40(3):352-7.

34. McCleskey EW, Gold MS. Ion channels and nociception. Annu Rev Physiol. 1999;61(1):835-56.

35. Mazzuca M, Heurteaux C, Alloui A, Diochot S, Baron A, Voilley N, et al. A tarantula peptide against pain via ASIC1a channels and opioid mechanisms. Nat Neurosci. 2007;10(8):943-5.

36. Park SP, Kim BM, Koo JY, Cho H, Lee CH, Kim M, et al. A tarantula spider toxin, GsMTx4, reduces mechanical and neuropathic pain. Pain. 2008;137(1):208-17.

37. Caterina MJ, Leffler A, Malmberg AB, Martin WJ, Trafton J, Petersen-Zeitz KR, et al. Impaired nociception and pain sensation in mice lacking the capsaicin receptor. Science. 2000;288(5464):306-13.

38. Jordt SE, Bautista DM, Chuang HH, McKemy DD, Zygmunt PM, Hogestatt ED, et al. Mustard oils and cannabinoids excite sensory nerve fibres through the TRP channel ANKTM1. Nature. 2004;427(1):260-5.

39. McKemy DD, Neuhausser WM, Julius D. Identification of a cold receptor reveals a general role for TRP channels in thermosensation. Nature. 2002;416(6876):52-8.

40. Story GM, Peier AM, Reeve AJ, Eid SR, Mosbacher J, Hricik TR, et al. ANKTM1, a TRP-like channel expressed in nociceptive neurons, is activated by cold temperatures. Cell. 2003;112(6):819-29.

41. Cortright DN, Szallasi A. TRP channels and pain. Curr Pharm Des. 2009;15(15):1736-49.

42. Strine TW, Kobau R, Chapman DP, Thurman DJ, Price P, Balluz LS. Psychological distress, comorbidities, and health behaviors among U.S. adults with seizures: results from the 2002 National Health Interview Survey. Epilepsia. 2005;46(7):1133-9.

43. Moreira SRG. Epilepsia: concepção histórica, aspectos conceituais, diagnóstico e tratamento. Mental. 2004;2(3):107-22.

44. Carey K, Fuchs S. Pediatric pharmacology. What you need to know for the next pediatric call. Emerg Med Serv. 2001;30(6):27-34.

45. Freitas RM, Viana GSB, Fonteles MMF. Níveis dos neurotransmissores estriatais durante o estado epiléptico. Rev Psiquiatr Clin (São Paulo). 2003;30(3):76-9. 
46. Clark S, Wilson WA. Mechanisms of epileptogenesis. Adv Neurol. 1999;79(1): 607-30.

47. Fujikawa DG, Itabashi HH, Wu A, Shinmei SS. Status epilepticus-induced neuronal loss in humans without systemic complications or epilepsy. Epilepsia. 2000;41(8):981-91.

48. Gupta RC, Dettbarn WD. Prevention of kainic acid seizures-induced changes in levels of nitric oxide and high-energy phosphates by 7-nitroindazole in rat brain regions. Brain Res. 2003;981(1-2):184-92.

49. Niquet J, Hantao L, Wasterlain CG. Programmed neuronal necrosis and status epilepticus. Epilepsia. 2005;46(Suppl 5):43-8.

50. Musicco M, Beghi E, Solari A, Viani F. Treatment of first tonic-clonic seizure does not improve the prognosis of epilepsy. First Seizure Trial Group (FIRST Group). Neurology. 1997;49(4):991-8.

51. Raza M, Shaheen F, Choudhary MI, Sombati S, Rafiq A, Suria A, et al. Anticonvulsant activities of ethanolic extract and aqueous fraction isolated from Delphinium denudatum. J Ethonopharmacol. 2001;78(1):73-8.

52. Lewis RJ, Garcia ML. Therapeutic potential of venom peptides. Nat Rev Drug Discov. 2003;2(10):790-802.

53. Cordeiro MN, Richardson M, Gilroy J, Figueiredo SG, Beirão PSL, Diniz CR. Properties of the venom from the South American "armed" spider Phoneutria nigriventer (Keyserling, 1891). Toxin Reviews. 1995;14(3):309-26.

54. Cordeiro MN, Diniz CR, Valentim AC, von Eickstedt VR, Gilroy J, Richardson M. The purification and amino acid sequences of four Tx2 neurotoxins from the venom of the Brazilian 'armed ' spider Phoneutria nigriventer (Keys). FEBS Lett. 1992;310(2):153-6.

55. Cordeiro MN, de Figueiredo SG, Valentim AC, Diniz CR, von Eickstedt VR, Gilroy $\mathrm{J}$, et al. Purification and amino acid sequences of six Tx3 type neurotoxins from the venom of the Brazilian 'armed' spider Phoneutria nigriventer (Keys). Toxicon. 1993;31(1):35-42.

56. Richardson M, Pimenta AM, Bemquerer MP, Santoro MM, Beirao PS, Lima ME, et al. Comparison of the partial proteomes of the venoms of Brazilian spiders of the genus Phoneutria. Comp Biochem Physiol C Toxicol Pharmacol. 2006;142(3-4):17387. 
57. Miranda DM, Romano-Silva MA, Kalapothakis E, Diniz CR, Cordeiro MN, Santos TM, et al. Phoneutria nigriventer toxins block tityustoxin-induced calcium influx in synaptosomes. Neuroreport. 1998;9(7):1371-3.

58. Miranda DM, Romano-Silva MA, Kalapothakis E, Diniz CR, Cordeiro MN, Santos TM, et al. Spider neurotoxins block beta-scorpion toxin-induced calcium uptake in rat brain cortical synaptosomes. Brain Research Bulletin. 2001;54(5): 533-6.

59. Guatimosim C, Romano-Silva MA, Cruz JS, Beirão PSL, Kalapothakis E, Moraes-Santos T, et al. A toxin from the spider Phoneutria nigriventer that blocks calcium channels coupled to exocytosis. Br J Pharmacol. 1997;122(3):591-7.

60. de Castro Junior CJ, Pinheiro AC, Guatimosim C, Cordeiro MN, Souza AH, Richardson $\mathrm{M}$, et al. Tx3-4 a toxin from the venom of spider Phoneutria nigriventer blocks calcium channels associated with exocytosis. Neurosci Lett. 2008;439(2):1702.

61. Pinheiro AC, da Silva AJ, Prado MA, Cordeiro MD, Richardson M, Batista MC, et al. Phoneutria spider toxins block ischemia-induced glutamate release, neuronal death, and loss of neurotransmission in hippocampus. Hippocampus. 2009;19(11):1123-9.

62. Martin-Moutot N, Mansuelle P, Alcaraz G, Dos Santos RG, Cordeiro MN, De Lima ME, Seagar M, Van Renterghem C. Phoneutria nigriventer toxin 1: a novel, state-dependent inhibitor of neuronal sodium channels that interacts with micro conotoxin binding sites. Mol Pharmacol. 2006;69(6):1931-7.

63. Romano-Silva MA, Ribeiro-Santos R, Ribeiro AM, Gomez MV, Diniz CR, Cordeiro $\mathrm{MN}$, et al. Rat cortical synaptosomes have more than one mechanism for $\mathrm{Ca}^{2+}$ entry linked to rapid glutamate release: studies using the Phoneutria nigriventer toxin PhTx2 and potassium depolarization. Biochem J. 1993;296(Pt 2):313-9.

64. Figueiredo SG, Garcia ME, Valentim AC, Cordeiro MN, Diniz CR, Richardson M. Purification and amino acid sequence of the insecticidal neurotoxin Tx4(6-1) from the venom of the 'armed' spider Phoneutria nigriventer (Keys). Toxicon. 1995;33(1):8393.

65. Figueiredo SG, de Lima ME, Cordeiro MN, Diniz CR, Patten D, Halliwell RF, et al. Purification and amino acid sequence of a highly insecticidal toxin from the venom of the Brazilian spider Phoneutria nigriventer which inhibits NMDA-evoked currents in rat hippocampal neurones. Toxicon. 2001;39(2-3):309-17. 
66. Gomez MV, Kalapothakis E, Guatimosin C, Prado MA. Phoneutria nigriventer venom: a cocktail of toxins that affect ion channels. Cell Mol Neurobiol. 2002; 22(56):579-88.

67. Oliveira LC, De Lima ME, Pimenta AM, Mansuelle P, Rochat, $H$, Cordeiro MN, et al. Pntx4-3, a new insect toxin from Phoneutria nigriventer venom elicits the glutamate uptake inhibition exhibited by PhTx4 toxic fraction. Toxicon. 2003;42(7):793-8.

68. Couraud F, Jover E, Dubois JM, Rochat H. Two types of scorpion receptor sites, one related to the activation, the other to the inactivation of the action potential sodium channel. Toxicon. 1982;20(1):9-16.

69. Catterall WA. Molecular properties of voltage-sensitive sodium channels. Annu Rev Biochem. 1986;55(1):953-85.

70. Wang CG, He XL, Shao F, Liu W, Ling MH, Wang DC, et al. Molecular characterization of an anti-epilepsy peptide from the scorpion Buthus martensi Karsch. Eur J Biochem. 2001;268(8):2480-5.

71. Zhao R, Zhang XY, Yang J, Weng CC, Jiang LL, Zhang JW, et al. Anticonvulsant effect of BmK IT2, a sodium channel-specific neurotoxin, in rat models of epilepsy. $\mathrm{Br}$ J Pharmacol. 2008;154(5):1116-24.

72. Lewington S, Clarke R, Qizilbash N, Peto R, Collins R. Age-specific relevance of usual blood pressure to vascular mortality: a meta-analysis of individual data for one million adults in 61 prospective studies. Lancet. 2002;360(9349):1903-13.

73. Chobanian AV, Bakris GL, Black HR, Cushman WC, Green LA, Izzo JL Jr, et al. The seventh report of the joint national committee on prevention, detection, evaluation, and treatment of high blood pressure: the JNC 7 Report. J Am Med Assoc. 2003; 289(19): 2560-72.

74. Lu X, Lu D, Scully MF, Kakkar VV. Integrins in drug targeting-RGD templates in toxins. Curr Pharm Des. 2006;12(22):2749-69.

75. McLane MA, Joerger T, Mahmoud A. Disintegrins in health and disease. Front Biosci. 2008;13(1):6617-37.

76. Gueron M, Ilia R, Shahak E, Sofer S. Renin and aldosterone levels and hypertension following envenomation in humans by yellow scorpion Leiurus quinquestriatus. Toxicon. 1992;30(7):765-7. 
77. Abroug F, Nouira S, El Atrous S, Besbes L, Boukef R, Boussarsar M, et al. A canine study of immunotherapy in scorpion envenomation. Intensive Care Med. 2003;29(12):2266- 76.

78. Ouanes-Besbes L, El Atrous S, Nouira S, Aubrey N, Carayon A, El Ayeb M, et al. Direct vs. mediated effects of scorpion venom: an experimental study of the effects of a second challenge with scorpion venom. Intensive Care Med. 2005;31(3):441-6.

79. Nouira S, Elatrous S, Besbes L, Boukef R, Devaux C, Aubrey N, et al. Neurohormonal activation in severe scorpion envenomation: correlation with hemodynamics and circulating toxin. Toxicol Appl Pharmacol. 2005;208(2):111-6.

80. Sun HY, Zhu HF, Ji YH. BmK I, an alpha-like scorpion neurotoxin, specifically modulates isolated rat cardiac mechanical and electrical activity. Sheng Li Xue Bao. 2003;55(5):530-4.

81. Rocha e Silva M, Beraldo WT, Andrade SO. A new factor (bradykinin) released from plasma globulin by snake venom and trypsin. Procedures of the First International Congress of Biochemistry; 1949. 119 p.

82. Bhoola KD, Figueroa CD, Worthy K. Bioregulation of kinins: kallikreins, kininogens, and kininases. Pharmacol Rev. 1992;44(1):1-80.

83. Blaukat A. Structure and signalling pathways of kinin receptors. Andrologia. 2003;35(1):17-23.

84. Marceau F, Larriveé JF, Saint-Jacques E, Bacharov DR. The kinin B1 receptor: an inducible G protein-coupled receptor. Can J Physiol Pharmacol. 1997;75(6):72530.

85. Regoli D, Jukie D, Gobeil F, Rhaleb NE. Receptors for bradykinin and related kinins: a critical analysis. Can J Physiol Pharmacol. 1993;71(8):556-67.

86. Regoli D, Barabe J. Pharmacology of bradykinin and related kinins. Pharmacol Rev. 1980;32(1):1-46.

87 Cushman DW, Cheung HS, Sabo EF, Rubin B, Ondetti MA. Development of specific inhibitors of angiotensin I converting enzyme (kininase II). Fed Proc. 1979;38(13):2778-82.

88. Cushman DW, Ondetti MA. Inhibitors of angiotensin-converting enzyme. Prog Med Chem. 1980;17(1):41-104.

89. Ondetti MA, Williams NJ, Sabo EF, Pluscec J, Weaver ER, Kocy O. Angiotensinconverting enzyme inhibitors from the venom of Bothrops jararaca. Isolation, elucidation of structure, and synthesis. Biochemistry. 1971;10(22):4033-9. 
90. Ianzer D, Konno K, Marques-Porto R, Vieira Portaro FC, Stöcklin R, Martins de Camargo AC, et al. Identification of five new bradykinin potentiating peptides (BPPs) from Bothrops jararaca crude venom by using electrospray ionization tandem mass spectrometry after a two-step liquid chromatography. Peptides. 2004;25(7):1085-92.

91. Ferreira LA, Alves EW, Henriques OB. Peptide T, a novel bradykinin potentiator isolated from Tityus serrulatus scorpion venom. Toxicon. 1993;31(8):941-7.

92. Verano-Braga T, Rocha-Resende C, Silva DM, lanzer D, Martin-Eauclaire MF, Bougis PE, et al. Tityus serrulatus hypotensins: a new family of peptides from scorpion venom. Biochem Biophys Res Commun. 2008;371(3):515-20.

93. Ferreira LA, Alves WE, Lucas MS, Habermehl GG. Isolation and characterization of a bradykinin potentiating peptide (BPP-S) isolated from Scaptocosa raptoria venom. Toxicon. 1996;34(5):599-603.

94. Meki AR, Nassar AY, Rochat H. A bradykinin-potentiating peptide (peptide K12) isolated from the venom of Egyptian scorpion Buthus occitanus. Peptides. 1995; 16(8):1359-65.

95. NIH Consensus Conference. Impotence NIH Consensus Development Panel on Impotence. JAMA. 1993;270(1):83-90.

96. Benet AE, Melman A. The epidemiology of erectile dysfunction. Urol Clin North Am. 1995;22(1):699-709.

97. Bivalacqua TJ, Usta MF, Champion HC, Kadowitz PJ, Hellstrom WJG. Endothelial dysfunction in erectile dysfunction: role of the endothelium in erectile physiology and disease. J Androl. 2003;24(6):S17-S37.

98. Eardley I, Fisher W, Rosen RC, Niederberger C, Nadel A, Sand M. The multinational men's attitudes to life events and sexuality study: the influence of diabetes on self-reported erectile function, attitudes and treatment-seeking patterns in men with erectile dysfunction. Int J Clin Pract. 2007;61(9):1446-53.

99. Leite R, Giachini FR, Carneiro FS, Nunes KP, Tostes RC, Webb RC. Targets for the treatment of erectile dysfunction: is NO/cGMP still the answer? Recent Pat Cardiovasc Drug Discov. 2007;2(2):119-32 .

100. Lewis RW, Fugl-Meyer KS, Bosch R, et al. Epidemiology/risk factors of sexual dysfunction. J Sex Med. 2004;1(1):35-9.

101. Priviero FB, Leite R, Webb RC, Teixeira CE. Neurophysiological basis of penile eretion. Acta Pharmacol Sin. 2007;28(6):751-5. 
102. Muller A, Mulhall JP. Cardiovascular disease, metabolic syndrome and erectile dysfunction. Curr Opin Urol. 2006;16(6):435-43 .

103. Bivalacqua TJ, Champion HC, Hellstrom WJG, Kadowitz PJ. Pharmacotherapy for erectile dysfunction. Trends Pharmacol Sci. 2000;21(12):484-9.

104. Giuliano FA, Rampin O, Benoit G, Jardin A. Neural control of penile erection. Urol Clin North Am. 1995;22(4):747-66.

105. Andersson KE, Wagner G. Physiology of penile erection. Physiol Rev. 1995;75(1):191-236.

106. Lue TF. Erectile dysfunction. New Engl J Med. 2000;342(24):1802-13.

107. Toda N, Ayajiki K, Okamura T. Nitric oxide and penile erectile function. Pharmacol Ther. 2005;106(2):233-66.

108. Ignarro LJ, Bush PA, Buga GM, Wood KS, Fukuto JM, Rajfer J. Nitric oxide and cyclic GMP formation upon electrical field stimulation cause relaxation of corpus cavernosum smooth muscle. Biochem Biophys Res Commun. 1990;170(2):843-50. 109. Burnett AL, Lowenstein CJ, Bredt DS, Chang TS, Snyder SH. Nitric oxide: a physiologic mediator of penile erection. Science. 1992;257(5068):401-3.

110. Rosselli M, Keller PJ, Dubey RK. Role of nitric oxide in the biology, physiology and pathophysiology of reproduction. Hum Reprod Update. 1998;4(1):3-24.

111. Rajfer J, Aronson WJ, Bush PA, Dorey FJ, Ignarro LJ. Nitric oxide as a mediator of relaxation of the corpus cavernosum in response to nonadrenergic, noncholinergic neurotransmission. N Engl J Med. 1992;326(2):90-4.

112. Stief CG, Noack T, Andersson KE. Signal transduction in cavernous smooth muscle. World J Urol. 1997;15(1):27-31.

113. Moreland RB, Goldestein I, Kim NN, Traish A. Sildenafil citrate, a selective phosphodiesterase type 5 inhibitor: research and clinical implications in erectile dysfunction. Trends Endocrinol Metab. 1999;10(3):97-104.

114. Lee MR, Li L, Kitazawa T. Cyclic GMP causes $\mathrm{Ca}^{2+}$ desensitization in vascular smooth muscle by activating the myosin light chain phosphatase. J Biol Chem. 1997;272(8):5063-8.

115. Nunes KP, Costa-Gonçalves A, Lanza LF, Cortes SF, Cordeiro MN, Richardson $\mathrm{M}$, et al. Tx2-6 toxin of the Phoneutria nigriventer spider potentiates rat erectile function. Toxicon. 2008;51(7):1197-206. 
116. Nunes KP, Cardoso FL, Cardoso Jr HC, Pimenta AMC, De Lima ME. Animal toxins as potential pharmacological tools for treatment of erectile dysfunction. In: Lima ME, Pimenta AMC, Martin-Eauclaire MF, Zingali RB, Rochat H (orgs). Animal toxins: state of the art. Perspectives in health and biotecnology. Belo Horizonte: Editora UFMG; 2009. 750 p.

117. Somlyo AP, Somlyo AV. Signal transduction by G-proteins, rho-kinase and protein phosphatase to smooth muscle and non-muscle myosin II. J Physiol. 2000;522(Pt 2):177-85.

118. Berger R, Billups K, Brock G, Broderick GA, Dhabuwala CB, Goldstein I, et al. Report of the American Foundation for Urologic Disease (AFUD) thought leader panel for evaluation and treatment priapism. Int J Impot Res. 2001;13(Suppl 5): S39S43.

119. Teixeira CE, Teixeira SA, Antunes E, De Nucci G. The role of nitric oxide on the relaxations of rabbit corpus cavernosum induced by Androctonus australis and Buthotus judaicus scorpion venoms. Toxicon. 2001;39(5):633-9.

120. Teixeira CE, de Oliveira JF, Baracat JS, Priviero FB, Okuyama CE, Rodrigues Netto $\mathrm{N} \mathrm{Jr}$, et al. Nitric oxide release from human corpus cavernosum induced by a purified scorpion toxin. Urology. 2004;63(1):184-9.

121. Andrade E, Villanova F, Borra P, Leite K, Troncone L, Cortez I, et al. Penile erection induced in vivo by a purified toxin from the Brazilian spider Phoneutria nigriventer. Br J Urol Int. 2008;102(7):835-7.

122. Escoubas P, Diochot S, Corzo G. Structure and pharmacology of spider venom neurotoxins. Biochimie. 2000;82(9-10):893-907.

123. De Lima ME, Figueiredo SG, Pimenta AM, Santos DM, Borges MH, Cordeiro $\mathrm{MN}$, et al. Peptides of arachnid venoms with insecticidal activity targeting sodium channels. Comp Biochem Physiol C Toxicol Pharmacol. 2007;146(1-2):264-79.

124. Catterall WA, Cestèle S, Yarov-Yarovoy V, Yu FH, Konoki K, Scheuer T. Voltage-gated ion channels and gating modifier toxins. Toxicon. 2007;49(2):24-141.

125. Matavel A, Cruz JS, Penaforte CL, Araujo DA, Kalapothakis E, Prado VF, et al. Electrophysiological characterization and molecular identification of the Phoneutria nigriventer peptide toxin Pn Tx2-6. FEBS Lett. 2002;523(1-3):219-23.

126. Matavel A, Fleury C, Oliveira LC, Molina F, de Lima ME, Cruz JS, et al. Structure and activity analysis of two spider toxins that alter sodium channel inactivation kinectics. Biochemistry. 2009;48(14):3078-88. 
127. Teixeira CE, Bento AC, Lopes-Martins RA, Teixeira SA, von Eickestedt V, Muscará MN, et al. Effect of Tityus serrulatus scorpion venom on the rabbit isolated corpus cavernosum and the involvement of NANC nitrergic nerve fibres. $\mathrm{Br} \mathrm{J}$ Pharmacol. 1998;123(3):435-42.

128. Teixeira CE, Faro R, Moreno RA, Rodrigues Netto N Jr, Fregonesi A, Antunes $E$, De Nucci G. Nonadrenergic, noncholinergic relaxation of human isolated corpus cavernosum induced by scorpion venom. Urology. 2001;57(4):816-20.

129. Teixeira CE, Ifa DR, Corso G, Santagada V, Caliendo G, Antunes E, De Nucci G. Sequence and structure-activity relationship of a scorpion venom toxin with nitrergic activity in rabbit corpus cavernosum. FASEB J. 2003;17(3):485-7.

130. Rego E, Bento AC, Lopes-Martins RAB, Antunes E, Novello JC, Marangoni S, et al. Isolation and partial characterization of a polypeptide from Phoneutria nigriventer spider venom that relaxes rabbit corpus cavernosum in vitro. Toxicon. 1996;34(10):1141-7.

131. Yonamine CM, Troncone LR, Camillo MA. Blockade of neuronal nitric oxide synthase abolishes the toxic effects of Tx2-5, a lethal Phoneutria nigriventer spider toxin. Toxicon. 2004;44(2):169-72.

132. Araújo DAM. Efeitos da fração neurotóxica, $P h T x 2$ e de suas isoformas purificadas, extraídas da peçonha da aranha Phoneutria nigriventer, sobre a corrente iônica [doctoral thesis]. Belo Horizonte, MG: Universidade Federal de Minas Gerais; 1992.

133. Villanova FE, Andrade E, Leal E, Andrade PM, Borra RC, Troncone LR, et al. Erection induced by Tx2-6 toxin of Phoneutria nigriventer spider: expression profile of genes in the nitric oxide pathway of penile tissue of mice. Toxicon. 2009;54(6):793-801. 134. Cury Y, Picolo G. Are animal toxins good models for analgesics? In: De Lima ME, Pimenta AMC, Martin-Eauclaire MF, Zingali R, Rochat $\mathrm{H}$, editors. Animal toxins: state of the art. Perspectives in health and biothecnology. Belo Horizonte: Editora UFMG; 2009. p. 661-78.

135. Billen B, Tytgat J. The venom of the Asian scorpion Buthus martensi Karsch: an overview of the toxins and their biological targets. In: De Lima ME, Pimenta, AMC, Martin-Eauclaire MF, Zingali $\mathrm{R}$, Rochat $\mathrm{H}$, editors. Animal toxins: state of the art. Perspectives in health and biothecnology. Belo Horizonte: Editora UFMG; 2009. p. 137-66. 
136. Santos WF, Coutinho-Netto J. Peptides from venoms acting on glutamatergic and gabaergic neurotransmition. In: De Lima ME, Pimenta AMC, Martin-Eauclaire MF, Zingali $\mathrm{R}$, Rochat $\mathrm{H}$, editors. Animal toxins: state of the art. Perspectives in health and biothecnology. Belo Horizonte: Editora UFMG; 2009. p .680-92.

137. Verano-Braga T, De Lima ME, Pimenta AMC. From bradykinin-potentiating peptides to hypotensins: more than four decades of research. In: De Lima ME, Pimenta AMC, Martin-Eauclaire MF, Zingali R, Rochat $\mathrm{H}$, editors. Animal toxins: state of the art. Perspectives in health and biothecnology. Belo Horizonte: Editora UFMG; 2009. p. 235-47.

138. Kuhn-Nentwig L. Cytolytic and antimicrobial peptides in the venom of scorpions and spiders. In: De Lima ME, Pimenta AMC, Martin-Eauclaire MF, Zingali R, Rochat $\mathrm{H}$, editors. Animal toxins: state of the art. Perspectives in health and biotechnology. Belo Horizonte: Editora UFMG; 2009. p. 153-72.

139. Bosmans F, Escoubas P, Nicholson GM. Spider venoms peptides as leads for drug and insecticide design. In: De Lima ME, Pimenta AMC, Martin-Eauclaire MF, Zingali $\mathrm{R}$, Rochat $\mathrm{H}$, editors. Animal toxins: state of the art. Perspectives in health and biothecnology. Belo Horizonte: Editora UFMG; 2009. p. 269-90.

140. Garcia M, Kaczorowski J. Animal toxins acting on ion channels. In: De Lima ME, Pimenta AMC, Martin-Eauclaire MF, Zingali R, Rochat $\mathrm{H}$, editors. Animal toxins: state of the art. Perspectives in health and biothecnology. Belo Horizonte: Editora UFMG; 2009. p. 639-50.

141. Strong P, Jeyaseelan K. Arthropod toxins acting on calcium-activated potassium channels. In: De Lima ME, Pimenta AMC, Martin-Eauclaire MF, Zingali R, Rochat H, editors. Animal toxins: state of the art. Perspectives in health and biothecnology. Belo Horizonte: Editora UFMG; 2009. p. 205-17.

142. De Lima ME, Pimenta AMC, Martin-Eauclaire MF, Zingali $R$, Rochat $H$, editors. Animal toxins: state of the art. Perspectives in health and biotechnology. Belo Horizonte: Editora UFMG; 2009. 